\title{
Cladistic analysis of the family Baetidae (Insecta: Ephemeroptera) in South America
}

\author{
C AR O L I N A N IE T O \\ INSUE-CONICET, Tucumán, Argentina
}

\begin{abstract}
The family Baetidae, which belongs to the order Ephemeroptera, was first described by Leach in 1815. Since then, almost 100 genera and 900 species have been described. Although diverse, this family is relatively homogeneous. The adults are extremely similar to one another, the wings vary little and the penes are membranous, features that significantly reduce differentiation among taxa. In contrast, the larvae have more conspicuous differences. Most are collector-gatherers, but a few are carnivorous or filter feeders. In South America, although knowledge concerning the 27 genera and 132 species of Baetidae described for this region has improved in the last three decades, phylogenetic relationships remain unknown. The present study, the first cladistic analysis of Baetidae in South America, included 70 species (55 are Neotropical) and 126 morphological characters. The matrix was analysed using TNT, under implied weights. Although the monophyly of the family Baetidae was obtained with good support, the subfamilies proposed originally (Baetinae, Cloeoninae and Callibaetinae) were recovered as paraphyletic. The Baetodes complex, as well as the relationships between genera, is discussed. The validity of some structures or characters as support of different groupings is also discussed.
\end{abstract}

\section{Introduction}

The family Baetidae belongs to the small order Ephemeroptera, distributed in almost all lentic and lotic aquatic systems. Ephemeroptera, or mayflies, include 37 known families and more than 3000 species (Brittain \& Sartori, 2003). Based on a species from Europe, Baetidae was one of the first families described in Ephemeroptera as Leach established in 1815. With almost 100 genera described and distributed all over the world, with the exception of New Zealand and Antarctica, it is one of the most diverse mayfly families. There is only one extinct genus described from the upper Cretaceous of Russia, described by Kluge (1997). Different authors have discussed the systematic position of this family within Ephemeroptera. Baetidae was included along with Siphlaenigmatidae in the superfamily Baetoidea in the infraorder Pisciforma (Kluge, 1997). Based on molecular data, Ogden \& Whiting (2005) recovered both this infraorder and this superfamily as paraphyletic, and Baetidae was

Correspondence: Carolina Nieto, Facultad de Ciencias Naturales e IML, INSUE-CONICET, Tucumán, Argentina. E-mail: macarolina_nieto@yahoo.com.ar recovered as sister to all other Ephemeroptera. The latest published study (Ogden et al., 2009) recovered Siphluriscus Ulmer as the sister group to all other mayflies, although the clade Baetidae + Isonychiidae was obtained as sister to the remaining clades of mayflies. Compared with other insect groups, this family presents a number of similar traits, a fact that renders the family relatively homogenous. In this sense, especially in the adult stage, their scarcely varied wings and their membranous penes are noticeable. However, major differences within the family are remarkable during the larval stage. One of these differences relates to their larval diet. In effect, although most are collector-gatherers, a few are carnivorous, e.g. South American Harpagobaetis Mol, and a third group is filter feeding, e.g. Chane Nieto; this latter genus exhibits a striking development of the maxillae and labium. Regarding habitats, they are diverse, with some genera, such as Mayobaetis Waltz \& McCafferty or Spiritops Lugo-Ortiz \& McCafferty, living in waterfalls, in temporary water with a poor current, such as Callibaetis Eaton, or even in fast flows, such as Baetodes Needham \& Murphy. As for the altitude range of their occurrence, Andesiops Lugo-Ortiz \& McCafferty is reported only above $1500 \mathrm{~m}$ elevation, whereas Journal compilation () 2010 The Royal Entomological Society 
Varipes Lugo-Ortiz \& McCafferty lives in the sandy substrate of lowland rivers. In South America, the first species was described in 1843 by Pictet, who named it Cloe fasciata.

The first and subsequent described species have big adults and a characteristic wing colour pattern, and belong to the most striking genus later established as Callibaetis. Since then, our knowledge of the family in South America has been greatly improved, especially in the last three decades. Currently, there are 27 genera, comprising 132 species, of which 60\% (17 genera) and 94\% (123 species) are endemic; the nonendemic genera are shared with North and Central America, with the only exception being the pantropical Cloeodes Traver. Two important factors contributed to a high degree of endemism, namely, the biogeographical history of South America, isolated for millions of years, and the low capacity of dispersal in this group. Although the knowledge of the family has improved in South America, the phylogenetic relationships of the main groups remain unknown, and only certain genera, such as Paracloeodes Day (Nieto \& Salles, 2006) and Cloeodes (Nieto \& Richard, 2008), have been studied cladistically. Other cladistic analyses for the family were proposed for Madagascar and Africa by Monaghan et al. (2005) and Gattolliat et al. (2008), but these studies were based upon molecular characters. Additional parsimony analyses have been carried out for other families, such as Leptophlebiidae (Flowers \& Domínguez, 1991; Domínguez, 1995, 1999; Domínguez et al., 2001) and Leptohyphidae (Molineri, 2004, 2006) in South America.

The studied material was collected from several regions of South America during field trips, and compiled together with borrowed and/or exchanged material from different institutions. It was the purpose of this work to test whether the South American genera belong to a single lineage and to establish the relationships between genera from this region. A morphological phylogeny including all genera and 55 species from South America was analysed using parsimony analysis. Thirteen species belonging to 11 genera from other biogeographical regions were included. More than 120 characters with different states were analysed; many of them proposed for the first time.

\section{Materials and methods}

The larvae were collected using traditional methods, with a kicknet and D-frame net the most useful. The light trap effectively captured adults, but rearing larvae provided an accurate association of both states. Both procedures were used to obtain the species for this study. All the material was conserved in $96 \%$ alcohol. For morphology, mature larvae and imagos were selected and dissected where possible. The subimagos, the intermediate state between larva and adult (exclusive to Ephemeroptera), were used only in a few cases, notably when larvae were reared to subimago only. The material examined is housed in the following institutions: Instituto Miguel Lillo, Tucumán, Argentina; Florida A \& M University, Tallahassee, FL, U.S.A.; Facultad de Ciencias de la República del Uruguay; Entomological Collection of the University of Missouri, Columbia; Instituto de Ecología, Unidad de Limnología, Universidad Mayor de San Andrés, La Paz, Bolivia.

Taxa

A matrix of 70 taxa, 68 of which belong to the family Baetidae (including all the South American genera), and 126 morphological characters was constructed. Fifty-four species are restricted to South America, four from North America, six from Central America, one from North and Central America, one from Central and South America, one from Europe and one from Africa. The species were selected when at least the larval state was described. The type species and one additional species were included to test the monophyly of the genera. Genera with many species, such as Baetodes and Camelobaetidius Demoulin, were prioritized in this analysis when both states, larva and adult, were described. The characters of ten species and only one genus, Adebrotus Lugo-Ortiz \& McCafferty, were excluded from the original description as material was not available (Table S1). To analyse the relationships of the South American genera within the family, genera from other regions were included, e.g. Acerpenna Waltz \& McCafferty (distributed in North America) was included because it was proposed as the sister taxon of Americabaetis Kluge (Lugo-Ortiz \& McCafferty, 1996b); Dabulamanzia LugoOrtiz \& McCafferty (from Madagascar) is close to Cloeodes (Gattolliat et al., 2008); Lugoiops McCafferty \& Baumgardner and Moribaetis Waltz \& McCafferty (from Central America) belong to the Baetodes complex (Lugo-Ortiz \& McCafferty, 1996a; McCafferty \& Baumgardner, 2003); this complex is analysed in detail in this paper. The trees were rooted with Metamonius Eaton (Nesameletidae) and Siphlaenigma Penniket (Siphlaenigmatidae), considered as the sister group of Baetidae (e.g. Landa \& Soldán, 1985; Kluge, 1997, 2004).

\section{Characters}

All characters described here derive from the external morphology of adults and larvae. The final characters chosen for the matrix were selected from among more than 200 characters proposed originally for the analysis. As some complex structures are extremely variable among genera, even among species, only the general shape was coded, for example the larval labium. Because of its variability, it was difficult to establish primary homologies with other taxa. One hundred and twenty-six external morphological characters were included in the analysis, most derived from larval morphology (105), 13 from the adult state and the rest (eight) from the male imago. Seventy-nine characters are binary and 47 are multistate; the latter characters were treated as nonadditive (unordered). The list of characters and their states is presented in Table S2 and the matrix is shown in Table S3.

Larval characters in the present work were analysed regardless of sex differences as there are almost no morphological 
differences between male and female larvae. In fact, only in a few cases is sexual dimorphism in the colour pattern observed. Therefore, the characters proposed here do not differ between sexes (Table S2). Most codified characters belonged to the larval head, especially the mouth apparatus. Among the mouthparts, the labium, labrum and mandibles provided the most characters (Table S2). In the thorax, the structure with more informative characters was the legs, especially the tarsal claws. In the abdomen, the gills, the terga and the cerci were the most informative structures. The colour pattern, although in many cases useful to recognize species, was excluded, as it was impossible to establish states among genera or even among species.

Adults provided fewer characters than larvae. In other families of Ephemeroptera, such as Leptophlebiidae or Leptohyphidae, the genitalia, especially the penes, has more informative characters. In Baetidae, the penes are not sclerotized and are impossible to code. Only the forceps have useful characters. Some coloration techniques have been used to identify differences in the internal anatomy of segments IX and X, although unsuccessfully for this study. The female imago does not provide particular characteristics in the genitalia. As the head has an atrophied mouth apparatus and the turbinate eyes present very few variations, both structures were not informative in this analysis. Contrary to Kluge's proposal of variable structures in the thorax of Ephemeroptera, no characters could be established in Baetidae. The wings, however, displayed some characters, especially the hind wings.

\section{Phylogenetic analysis}

The matrix was analysed using TNT (Goloboff et al., 2003a), under implied weights (Goloboff, 1993). The shortest trees were obtained under Analyze/TraditionalSearch commands, i.e. 500 replicates of random addition sequences followed by tree bisection-reconnection, saving ten trees per replication. After obtaining the shortest trees, the value of homoplasy for each character was calculated (homoplasy adjustment). Characters with low homoplasy present values near 0.00 , whereas characters with high homoplasy have values near one (some are mentioned in the results). Group support was obtained by applying three estimators, absolute and relative Bremer supports (Bremer, 1988, 1994) and frequency differences (Goloboff et al., 2003b). Bremer supports were calculated for the most-parsimonious trees and 12000 suboptimal trees up to five steps longer. Suboptimal trees were distributed in 12 stages: $0.1,0.2,0.3,0.4,0.5,1,2,3,4,5,7$ and 10 units of fit, saving 1000 trees at each stage. Frequency differences were calculated with 500 replicates of jackknifing (Farris et al., 1996) by symmetrical resampling of the original matrix (each character presents the same probability of being positively or negatively reweighted; Goloboff et al., 2003b). Each replicate of jackknifing was calculated by ten random addition sequences plus tree bisection-reconnection, saving ten trees per replicate.

\section{Results and discussion}

Analysis under implied weights obtained three shortest trees (length $=801$ steps, fit $=70.12$ ). Figure 73 shows the strict consensus of the shortest trees with Metamonius as the outgroup. The result did not change with Siphlaenigma as the outgroup. As many authors have argued, the monophyly of the family Baetidae is confirmed. In this analysis, the 16 synapomorphies and the good support values obtained under the three estimators support this result (node A). Larval synapomorphies are: frontoclypeal suture at the level or above the ocelli (character 0); labrum, apical margin with an anteromedial emargination and small medial lobe (character 14); prostheca of left mandible without transverse seta (character 28); paraglossae equal in length to glossae (character 45); abdominal terga with cover and some scales (character 88 ). In the adults, male eyes turbinate (character 105); fore tarsal claws with one claw hooked, one blunt (character 107); protarsi with four tarsomeres (character 109); fore wings with marginal intercalary double veins (character 111); marginal intercalary free veins (character 112); fork MA1-MA2 (character 114) absent; fore wings with few cross-veins (character 116); hind wings with three veins, the second one bifurcated, costal projection pointed (character 118); hind wings with less than nine cross-veins (character 119); forceps with three segments (character 120); penes not sclerotized (character 125). The South American genera appeared to be related to genera from other biogeographical regions, indicating more than one phylogenetic lineage, as discussed above.

The present analysis recovered three main groups of Baetidae (nodes B, C, D) (Fig. 73). Node B includes the Baetodes complex (Lugo-Ortiz \& McCafferty, 1996a; McCafferty \& Baumgardner, 2003) plus Spiritiops Lugo-Ortiz \& McCafferty. The Baetodes complex (Lugo-Ortiz \& McCafferty, 1996a) originally included four genera: Baetodes, Mayobaetis, Moribaetis, Prebaetodes Lugo-Ortiz \& McCafferty. Later, Lugoiops was included in this complex by McCafferty \& Baumgardner (2003). This complex was established based on the tarsal claws in the larvae with a strong subapical seta. In this analysis, this character (83) is a synapomorphy of node B. Spiritiops, originally excluded from the complex, was recovered in the base of this group. The groups recovered in node B with support values above 30 in jackknifing were: Lugoiops + Baetodes (node E) supported by two synapomorphies, i.e. the labrum dorsally and basally raised (character 15) and the terminal filament reduced to one or two segments (character 100). The second synapomorphy is the same as that obtained by McCafferty \& Baumgardner (2003). They proposed another two synapomorphies: (i) bare cerci; although Baetodes cerci look bare, under a microscope they have simple setae (this state was not used in this analysis); (ii) the gills are not outspread or held dorsal to abdominal pleura (coded as character 96). This character is not especially clear in Fig. 1 of Lugoiops (McCafferty \& Baumgardner, 2003). However, the present analysis supports this character as a synapomorphy of the genus Baetodes (Table S2). Mayobaetis + Lugoiops + Baetodes (node F) is supported by seven synapomorphies. The labrum with lateral margins on 

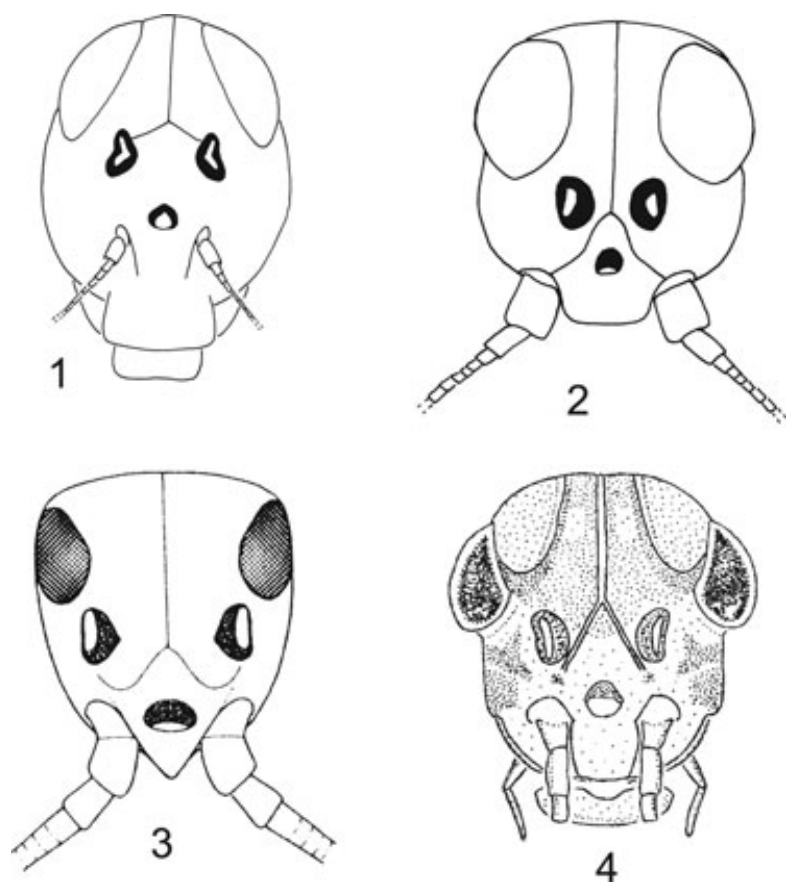

Figs 1-4. Larval heads. 1, Metamonius anceps; 2, Baetodes sp.; 3, Fallceon planifrons; 4, Apobaetis fiuzai [Figs 1-2 modified from Domínguez et al. (2006), Fig. 3 modified from Kluge (1992) and Fig. 4 modified from Salles \& Lugo-Ortiz (2002)].

sclerotized ventral surface (character 9) and the labrum with ventral setae (character 16) were the characters with the best values of homoplasy adjustment (0.25). Mayobaetis was recovered as the sister group of Lugoiops + Baetodes instead of Prebaetodes as proposed by McCafferty \& Baumgardner (2003). Prebaetodes + Mayobaetis + Lugoiops + Baetodes (node G) is supported by six synapomorphies. The posterior margin of smooth paraprocts (character 97) had the best homoplasy adjustment (0.00). The differences between the results obtained here and the results obtained by Lugo-Ortiz \& McCafferty (1996a) and McCafferty \& Baumgardner (2003) are probably due to the characters they used; they codified the same structure under different characters. This is the case, for example, in the length of the terminal filament, named the middle tail, which was codified at least three times (some shortening, additional shortening, more shortening). The legs are codified as robust or elongate; however, these two states are not so clear when all the genera involved are compared. The larvae of this complex are characterized for being clingers and rheophilous. In some species, such as Moribaetis macaferti, Mayobaetis ellenae and Baetodes rutilus, the larvae also live in splash zones of waterfalls (Waltz \& McCafferty, 1985; McCafferty \& Lugo Ortiz, 1998; Nieto, 2004). Lugo-Ortiz \& McCafferty (1996a) considered this last characteristic as a plesiomorphic state to be present in the plesiotypic members of the complex. This analysis did not recover these species in a basal position and it was not possible to confirm this hypothesis.

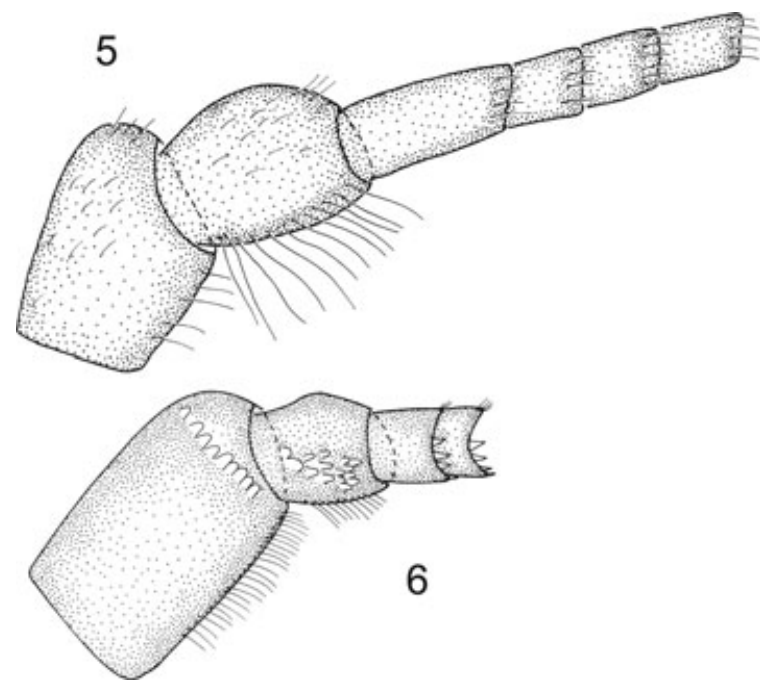

Figs 5-6. Antennae. 5, Baetodes cochunaensis; 6, Mayobaetis sp.

Node C sustains the second main group of genera in this analysis. Procloeon pennulatum is placed at the base of this node. This species, distributed in Asia, Europe and North America, is placed within a group of genera such as Apobaetis Day, Varipes, Paracloeodes and Callibaetis, widely distributed in America. The groups recovered in this node (support values above 30 in jackknifing) were: Rivudiva LugoOrtiz \& McCafferty + Varipes (node I), supported by seven synapomorphies (Table S4). In this node, the ventral margin of the femora with a row of very long setae (character 64) had the best homoplasy adjustment (0.00) (Fig. 45). Waltzohyphius McCafferty \& Lugo-Ortiz + Callibaetis (node J) is supported by four synapomorphies. Character 42 , with maxillae with a longitudinal row of long setae at the apex of the crown, had the best homoplasy adjustment (Fig. 30). Habitat was not codified as a character in this matrix. However, these two genera have one trait in common, i.e. to be found in low current. Paracloeodes + Waltzohyphius + Callibaetis (node $\mathrm{K}$ ) is supported by the right mandible with an inner set of incisors at right angle to the outer set (character 22) (Fig. 22).

The third main group of genera is placed in the base of node D. The first group recovered was Chane + Guajirolus Flowers (node L). With the best support obtained, this group shares 11 synapomorphies (Table S4). Among these characters, the mandibles (Fig. 17), with prosthecae inserted in a concavity (character 18), had the best homoplasy adjustment $(0.00)$. The tarsal claws (Fig. 51), with the highly developed subapical denticle (character 82), are the most conspicuous character to distinguish this group of genera from the others. These two genera are found in rivers with sandy substrate. Corinnella Thomas \& Dominique + Camelobaetidius (node M) is supported by four synapomorphies. The spatulated tarsal claws (character 80), present only in this node (Fig. 46), are unique in the family, even in the order. Although Berner \& Pescador (1988) proposed that this claw was used by the larvae in 


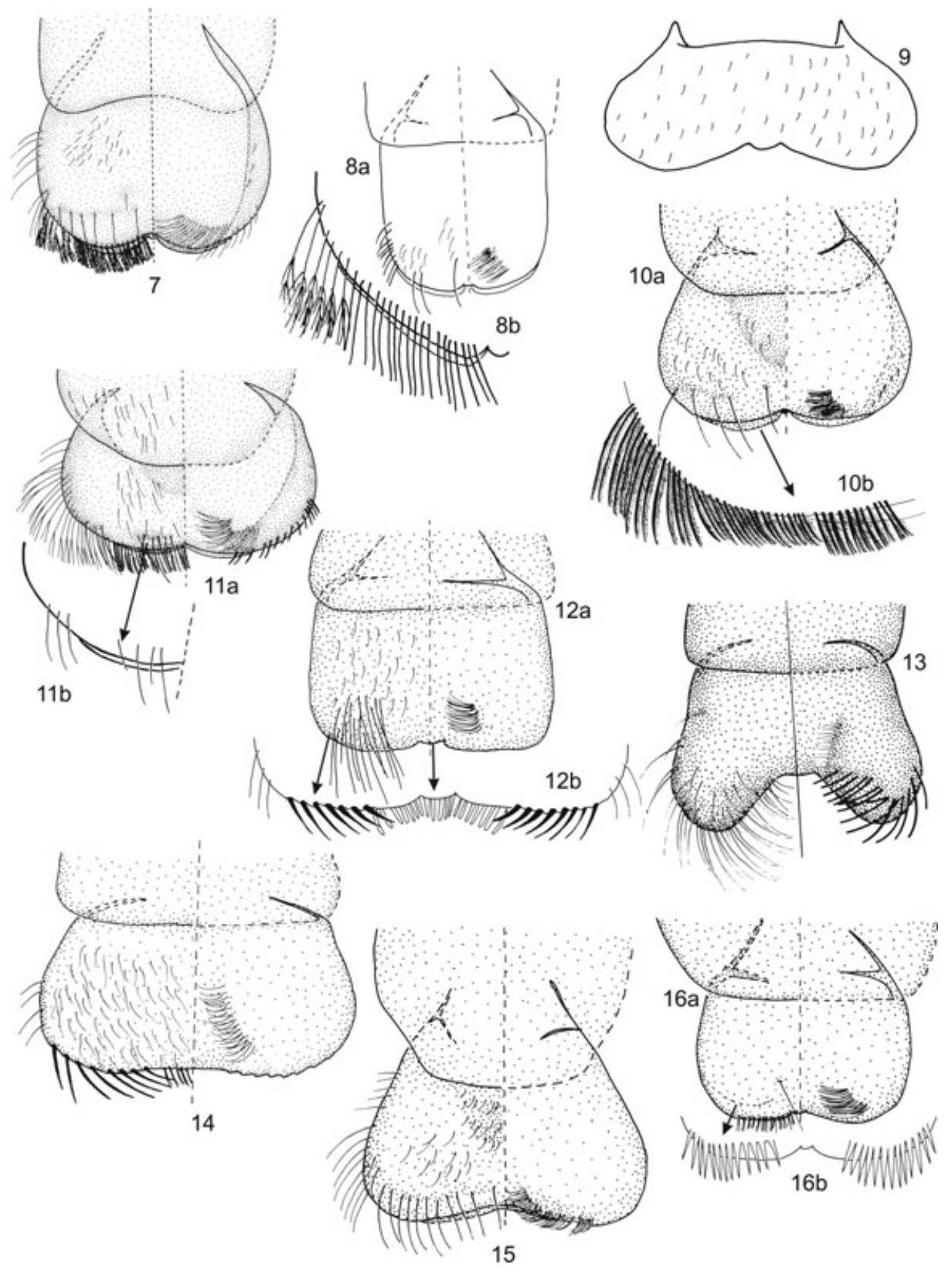

Figs 7-16. Labrum. 7, Mayobaetis sp., left dorsal view (d.v.), right ventral view (v.v.); 8a, Tupiara ibirapitanga, left d.v., right v.v.; 8b, labrum: apical setae d.v.; 9, Harpagobaetis gulosus d.v.; 10a, Moribaetis macaferti left d.v., right v.v.; 10b, labrum: apical setae d.v.; 11a, Baetodes cochunaensis, left d.v., right v.v.; 11b, labrum: subapical setae d.v.; 12a, Waltzohyphius fasciatus, left d.v., right v.v.; 12b, labrum: apical setae d.v.; 13, Chane baure, left d.v., right v.v.; 14, Apobaetis kallawaya, left d.v., right v.v.; 15, Moribaetis maculipennis, left d.v., right v.v.; 16a, Aturbina georgei, left d.v., right v.v.; 16b, labrum: subapical setae d.v.

fast currents, larval Camelobaetidius can be found in habitats with low or fast currents. That the main function of this tarsal claw is related to scraping algae for feeding is more accepted (Perry, 2005; Baptista et al., 2006). Node O, with low support, contains four genera: Fallceon Waltz \& McCafferty, Harpagobaetis, Heterocloeon McDunnough and Andesiops. This node is supported by character 84 , which is tarsal claws with a pair of subapical setae (Fig. 49). This character was considered by Lugo-Ortiz et al. (1994) as unstable because it is variable even among species of the same genus. Here, this character was obtained only once in the tree and supports four genera. Lugo-Ortiz \& McCafferty (1998) proposed an afrotropical complex to include Cloeodes and three more genera: Crassabwa Lugo-Ortiz \& McCafferty, Dabulamanzia and Nesydemius Lugo-Ortiz \& McCafferty, with the distinctive subproximal arc of setae on the tibiae being synapomorphic. 

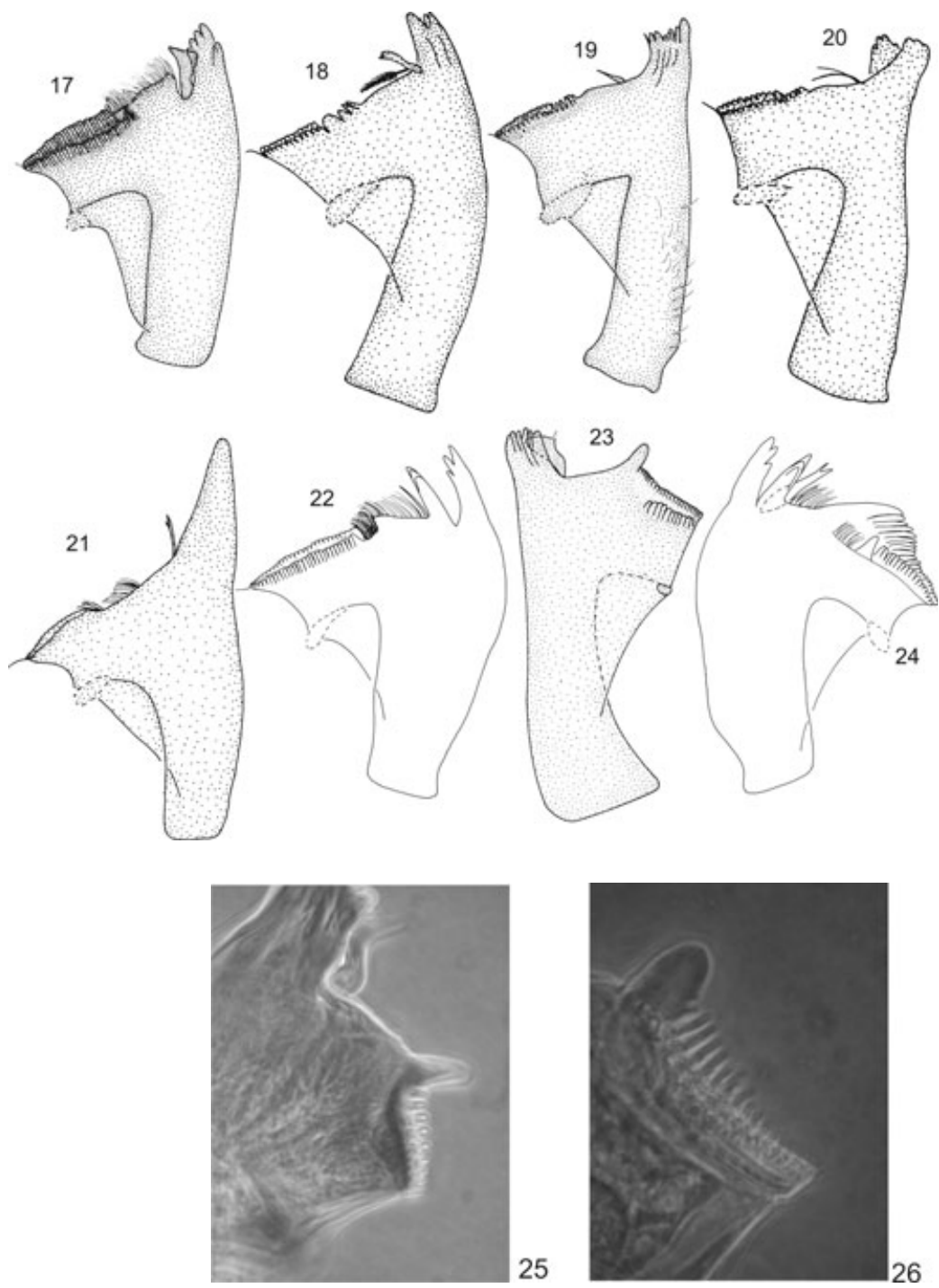

Figs 17-24. Mandibles. 17-22, right mandibles. 17, Guajirolus queremba; 18, Aturbina georgei; 19, Baetodes huaico; 20, Andesiops peruvianus; 21, Moribaetis maculipennis; 22, Callibaetis radiatus; 23, 24, left mandibles. 23, Camelobaetidius suapi; 24, Callibaetis radiatus.

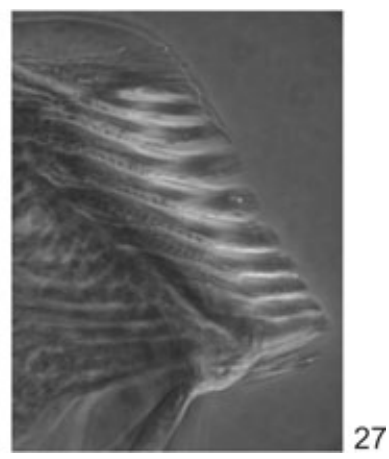

Figs 25-27. Left mandibles. 25, Camelobaetidius anubis, 26, Varipes cajuato, 27, Metamonius anceps.

Gattolliat et al. (2008) obtained at least a diphyletic origin for this complex and could not demonstrate if Dabulamanzia is the sister group of Cloeodes. In this analysis, this complex was not under revision, but Dabulamanzia from Madagascar and Cloeodes with a pantropical distribution were recovered as sister groups (node N). Four synapomorphies sustain node $\mathrm{N}$ (Table S4), one of which is character 76; that is, subproximal arc of setae on the tibiae had the best homoplasy adjustment, 0.00 (Fig 40a).

\section{Genera}

Thirteen speciose genera out of 15 were recovered as monophyletic; only Cryptonympha Lugo-Ortiz \& McCafferty and Americabaetis were paraphyletic. Eleven were recovered with optimal supports (above 60), namely, Andesiops, Aturbina
Lugo-Ortiz \& McCafferty, Baetodes, Callibaetis, Camelobaetidius, Cloeodes, Guajirolus, Mayobaetis, Moribaetis, Rivudiva, Varipes, whereas Apobaetis and Paracloeodes had values under 35 (Table S4 with the list of synapomorphies for each genus). However, exploratory research shows that the support of Apobaetis and Paracloeodes increases when the species A. etowah and P. abditus are temporarily omitted from the analysis. Extracted from the literature, both species lack sufficient data. Table S4 shows the list of the synapomorphies of each genus obtained in this analysis. Americabaetis was established originally as a subgenus of Baetis Leach (Kluge, 1992) and later as a genus from South America. The main diagnostic characters proposed for this genus are based on the absence of some structures, that is, absence of gills I, absence of hind wing pads, and absence of conical processes between the male genital forceps (Lugo-Ortiz \& McCafferty, 1996b). Other diagnostic characters, such as the presence of 


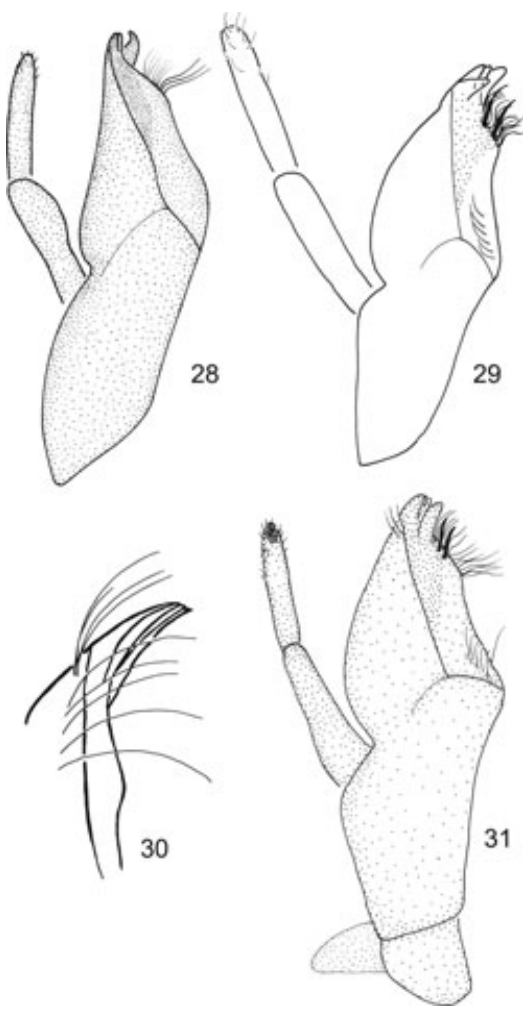

Figs 28-31. Maxillae. 28, Camelobaetidius apis; 29, Americabaetis alphus; 30, Waltzohyphius fasciatus, apical portion; 31, Moribaetis macaferti.

setae between prostheca and mandible mola (here characters 23 and 29) or segment II of labial palpi with a digitiform projection (character 51), were obtained here with a poor homoplasy adjustment (0.77-0.80). The description of this genus based on absences plus homoplastic characters probably explains the paraphyly obtained in this analysis for Americabaetis.

Cryptonympha, which has similar problems and results, was established by Lugo-Ortiz \& McCafferty (1998) from Brazil. When Salles \& Francischetti (2004) described the second species of this genus, C. dasilvai, some generic characters changed and the sustaining synapomorphies remain unclear [see discussion in Salles \& Francischetti (2004)] with the exception of right mandible prostheca with a transverse seta (character 19). In this analysis, the low homoplasy adjustment (0.50) is inadequate to support monophyly. Both Americabaetis and Cryptonympha need to be analysed better to clarify either the synapomorphies of these genera or their validity.

\section{Subfamilies}

Three subfamilies were originally proposed in Baetidae Gillies (1991): Baetinae Leach, Callibaetinae Riek and Cloeoninae Kazlauskas. These groups were established based on marginal intercalary veins being paired in Baetinae and single in Cloeoninae; setal tuft on the right mandible absent in Cloeoninae and present in Baetinae; denticles of the tarsal claws appear in one row or are absent in Baetinae and in two rows in Cloeoninae. Callibaetinae, including only Callibaetis, was treated as a distinct and homogeneous group characterized by an ornamented cuticle. In this analysis, species of the three possible subfamilies were included (Table S1 and Fig. 73). Although these data were not enough to clarify all the suprageneric systematics of the family in the world, it is possible to extract some conclusions. The three main groups recovered here (nodes B, C, D) (Fig. 73) do not correspond with subfamilies proposed previously. Callibaetinae is clearly a monophyletic group, but it is nested to other genera from other subfamilies. Baetinae and Cloeoninae were recovered as paraphyletic. Furthermore, the correlation proposed by Gillies (1991) between the marginal veins of wings (character 111), the rows of denticles in the tarsal claws (character 81) and the setal tuft on the right mandible (character 23) was not found. However, as observed by Gillies (1991), the paired marginal veins, the absence of a setal tuft on the right mandible and the tarsal claws with one row are more frequent in South America.

Kluge (1997) proposed five subfamilies, namely, the three subfamilies cited above together with Palaeocloeoninae and Afroptilinae, which are not treated here. This classification was proposed with no analytical methodology as no character states matrix was presented. Consequently, his conclusions are difficult to test. Besides, it is not clear which characters sustain the three subfamilies tested here, except for the paired marginal veins in Baetinae and single veins in Cloeoninae. Kluge (1997) proposed two more characters for larvae. The first was abdominal terga with scales with two covers on its corners, a character that presents several reversions; the second referred to the position of the subimaginal forceps under the cuticle of mature larvae, for which Kluge proposed at least six states. The present analysis found that the former character is insufficient to reach conclusions for the subfamilies proposed. When it was analysed within the whole matrix (character 88), it mapped in different places and was obtained with poor homoplasy adjustment (0.82). As for the latter character, which was not included in the matrix, Kluge's proposal could not be corroborated due to the very few specimens showing the alleged structure.

\section{Conclusion}

This analysis was the first study of the relationships of Baetidae taxa in South America. The most supported conclusions are:

1 The monophyly of the family Baetidae is highly supported under the three estimators used.

2 In South America, three main groups, nodes B, C and $\mathrm{D}$, were recovered. With a few exceptions, node $\mathrm{B}$ has concentrated genera distributed in the Andean Region (Morrone, 2001), node $\mathrm{C}$ has genera distributed in the Amazonic and Paranaense subregions (Morrone, 2001). Node D combines genera restricted to the Neotropical region (Chane, Harpagobaetis, Nanomis Lugo-Ortiz \& McCafferty, Tomedontus Lugo-Ortiz \& McCafferty, etc.) 

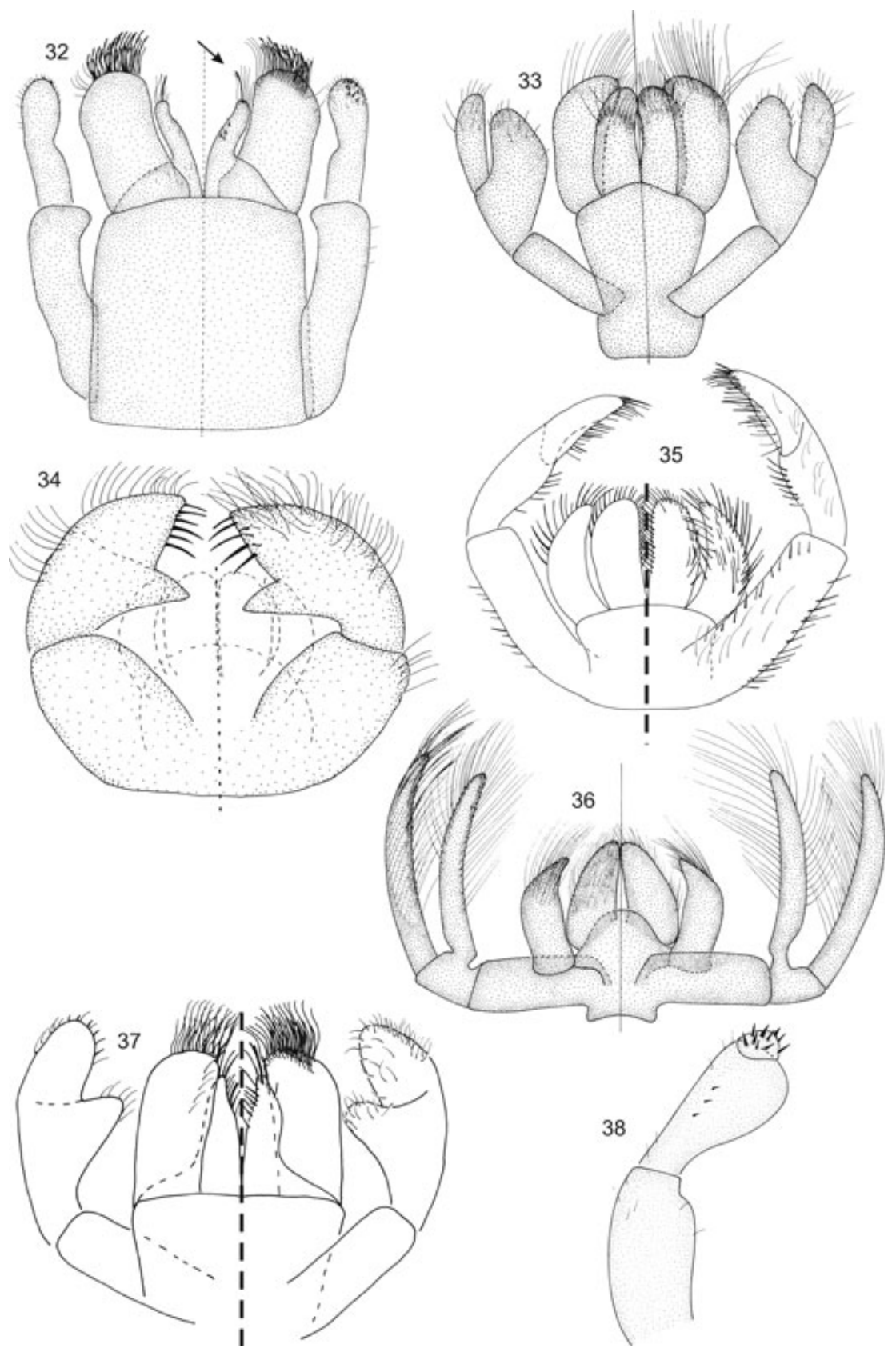

Figs 32-38. Labium. 32, Baetodes cochunaensis, left dorsal view (d.v.), right ventral view (v.v.); 33, Guajirolus queremba, left d.v., right v.v.; 34, Apobaetis kallawaya, left d.v., right v.v.; 35, Callibaetis radiatus, left d.v., right v.v.; 36, Chane baure, left d.v., right v.v.; 37, Americabaetis alphus, left d.v., right v.v.; 38, Camelobaetidius apis, palp.

with genera from Nearctic (Acerpenna and Heterocloeon) and Afrotropical areas (Dabulamanzia).

3 The genera distributed in North and Central America, Europe and Madagascar (Acerpenna, Heterocloeon, Lugoiops, Moribaetis, Fallceon, Procloeon Bengtsson and Dabulamanzia) were recovered within the South American genera, indicating a pre-Gondwana break-up origin of the groups.
4 Although several authors (Kazlauskas, 1972; Landa \& Soldán, 1985; Gillies, 1991; Kluge, 1997) support the validity of Baetinae, Cloeoninae and Callibaetinae, these subfamilies were recovered as paraphyletic. The correlation proposed by Gillies (1991) between two characters in the larva and one character in the adult was not demonstrated here. The characters proposed by Kluge were insufficient to distinguish these subfamilies either. 


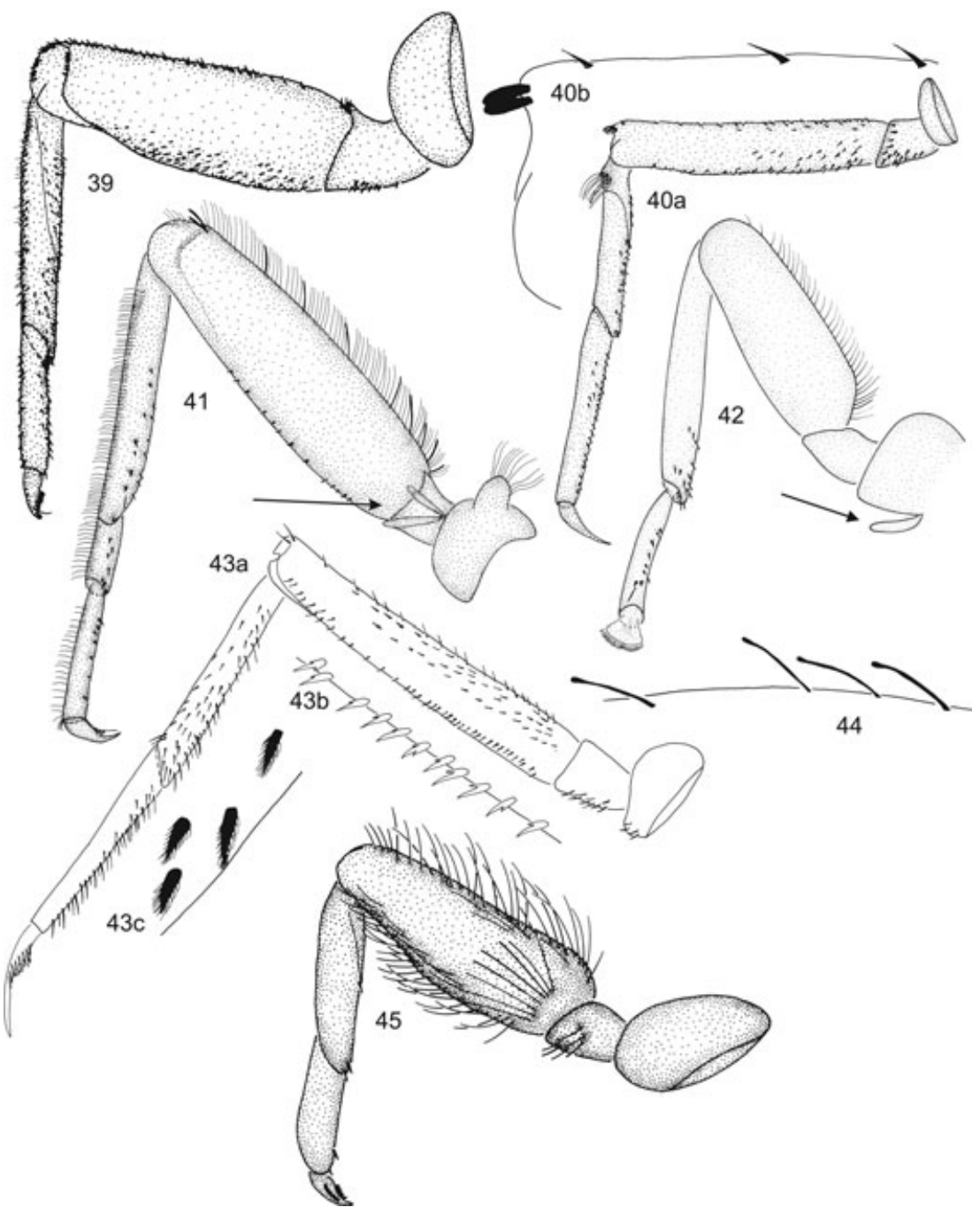

Figs 39-45. Legs. 39, Moribaetis macaferti; 40a, Cloeodes espinillo; 40b, dorsal margin of femur I; 41, Baetodes huaico; 42, Camelobaetidius apis; 43a, Callibaetis radiatus; 43b, femur ventral margin; 43c, tibia ventral margin; 44, Nanomis galera, femur dorsal margin; 45, Varipes cajuato.

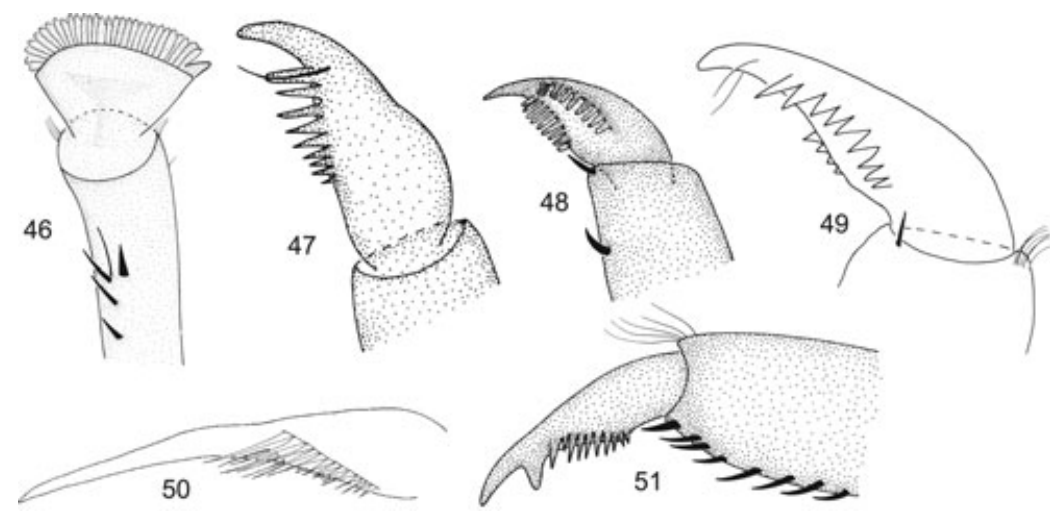

Figs 46-51. Tarsal claws. 46, Camelobaetidius apis; 47, Moribaetis macaferti; 48, Varipes cajuato; 49, Andesiops ardua; 50, Callibaetis willineri; 51, Guajirolus queremba. 


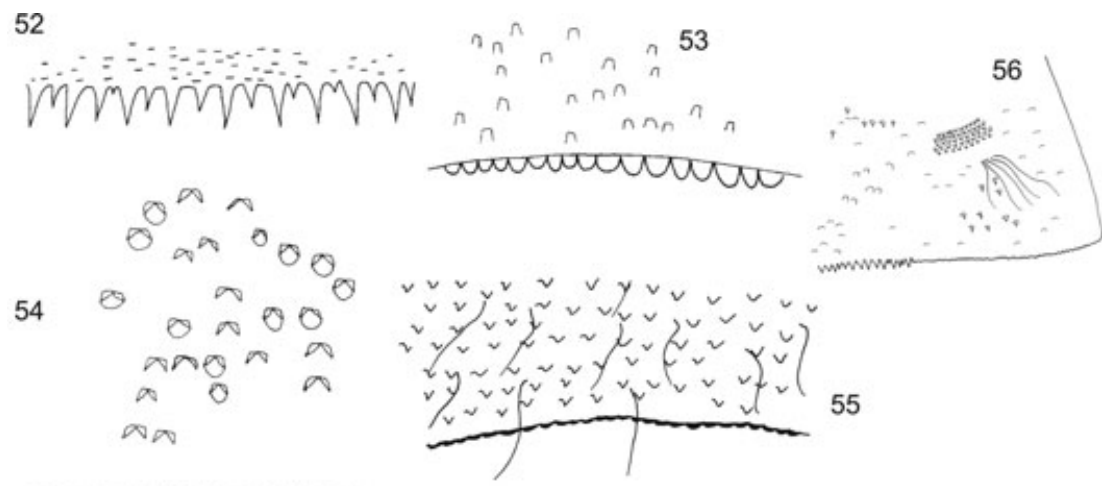

\section{TWWWWWWW}

Figs 52-56. Terga. 52, Callibaetis gonzalezi; 53, Prebaetodes sitesi; 54, Moribaetis maculipennis; 55, Apobaetis kallawaya; 56, sternum, Cloeodes espinillo.

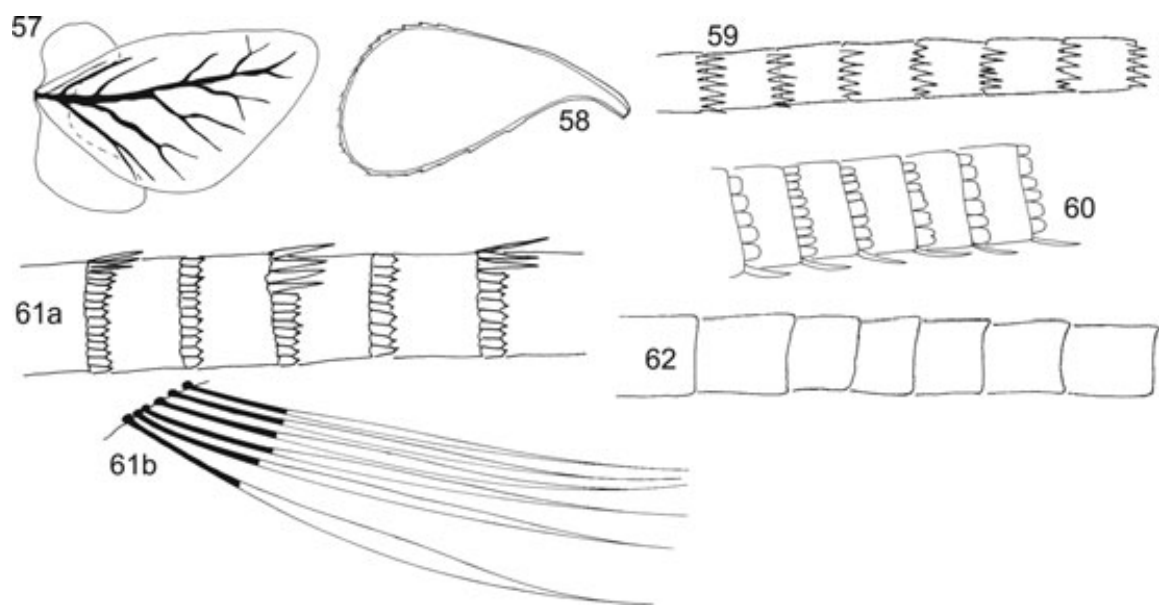

Figs 57-62. Gills. 57, Callibaetis radiatus; 58, Varipes minutus; 59-62, cerci; 59, Callibaetis willineri; 60, Mayobaetis sp.; 61a, Cloeodes espinillo; 61b, lateral setae detail; 62, Apobaetis kallawaya.

5 The suprageneric classification for Baetidae is still not resolved. A further and more detailed analysis of the problem is necessary if this issue is to be approached seriously. Thus, studies including more genera from other biogeographical regions of the world should be carried out, especially those genera of gondwanan distribution.

6 The inclusion of molecular data should provide additional information about the relationships, especially the nodes with low support that morphological characters cannot resolve.

7 Prior to this analysis, a few sister relationships among genera were proposed. Here, sister groups such as Baetodes + Lugoiops + Mayobaetis; Varipes + Rivudiva + Apobaetis; Callibaetis + Waltzohyphius + Paracloeodes; Camelobaetidius + Corinnella ; Cloeodes + Dabulamanzia are proposed. The Baetodes complex proposed in this region was recovered with one more genus, Spiritiops, although some relationships are different.
8 Except Americabaetis and Cryptonympha, the remaining 13 speciose genera were recovered as monophyletic.

\section{Supporting Information}

Additional Supporting Information may be found in the online version of this article under the DOI reference: DOI: 10.1111/j.1365-3113.2010.00523.x

Table S1. List of taxa in the matrix.

Table S2. Characters and character states.

Table S3. Matrix List of synapomorphies common to three trees obtained.

Table S4. List of synapomorphies common to three trees obtained.

Please note: Neither the Editors nor Wiley-Blackwell are responsible for the content or functionality of any 

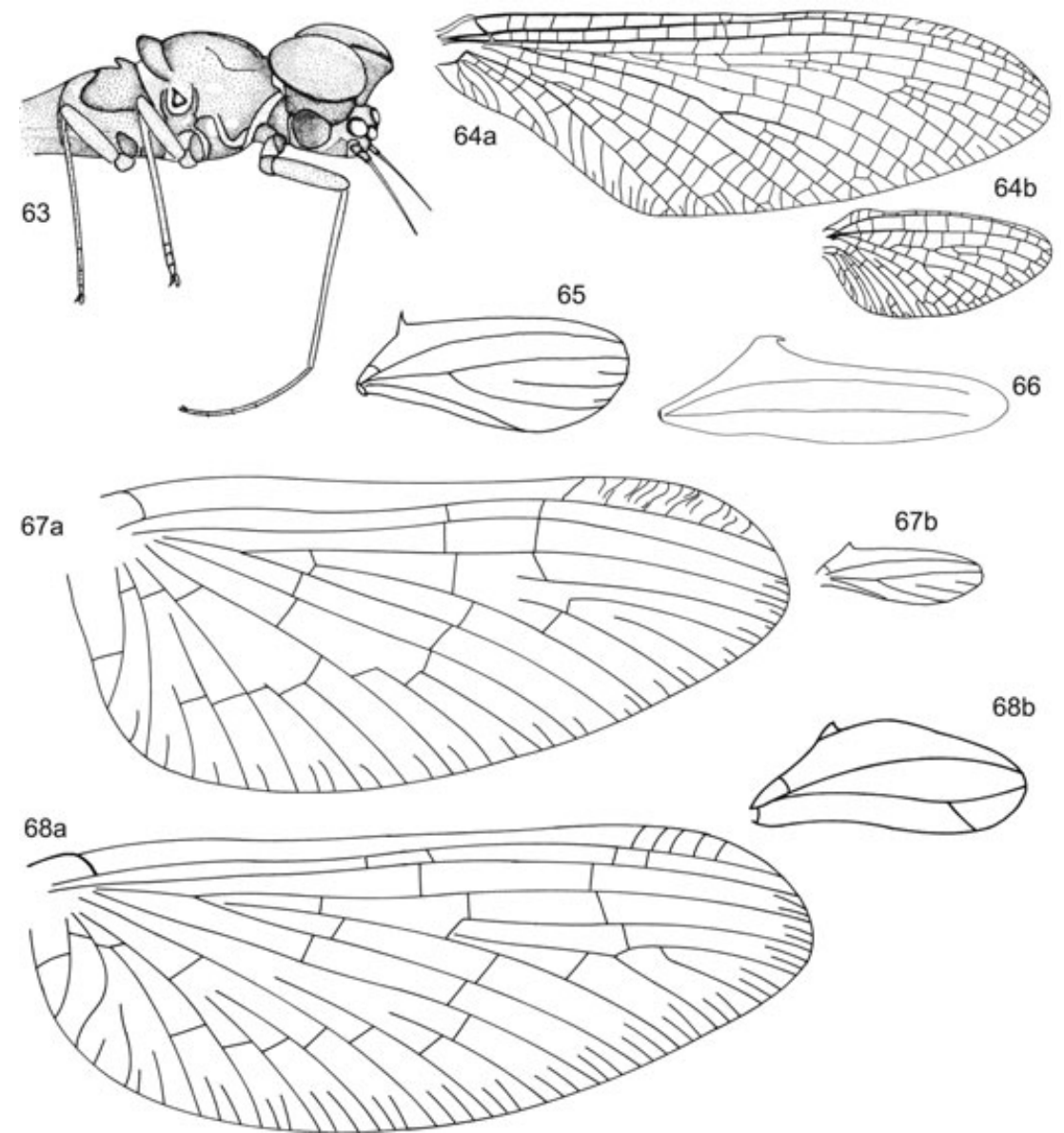

Figs 63-68. Adults. 63, Chane baure, lateral view. 64a, Metamonius anceps, fore wing; 64b, hind wing. 65, Nanomis galera, hind wing. 66, Aturbina georgei; 67a, Andesiops torrens fore wing; 67b, hind wing; 68a, Mayobaetis sp., fore wing; 68b, hind wing.
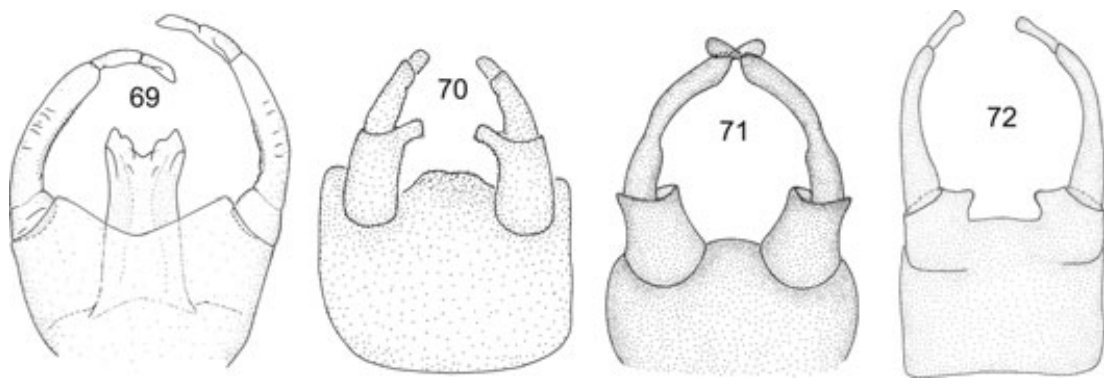

Figs 69-72. Male genitalia. 69, Metamonius anceps; 70, Aturbina beatrixae; 71, Chane baure; 72, Baetodes huaico.

supporting materials supplied by the authors. Any queries (other than missing material) should be directed to the corresponding author for the article.

\section{Acknowledgements}

Carlos Molineri and Eduardo Domínguez provided helpful comments and discussion during this study. The valuable suggestions of Luisa Montivero and the two anonymous reviewers are appreciated. The author thanks the Willi Hennig Society for making the program TNT free and available. The following institutions are acknowledged for the loan of some material: Florida A \& M University; Facultad de Ciencias de la República del Uruguay; University of Missouri; Universidad Mayor de San Andrés. Financial support from Consejo Nacional de Investigaciones Científicas y Técnicas (CONICET), to which the author belongs, is acknowledged. This research was partially supported by the following grants: FONCyT 524 and 528.

(C) 2010 Consejo Nacional de Investigaciones Científicas y Técnicas Journal compilation (c) 2010 The Royal Entomological Society, Systematic Entomology, 35, 512-525 


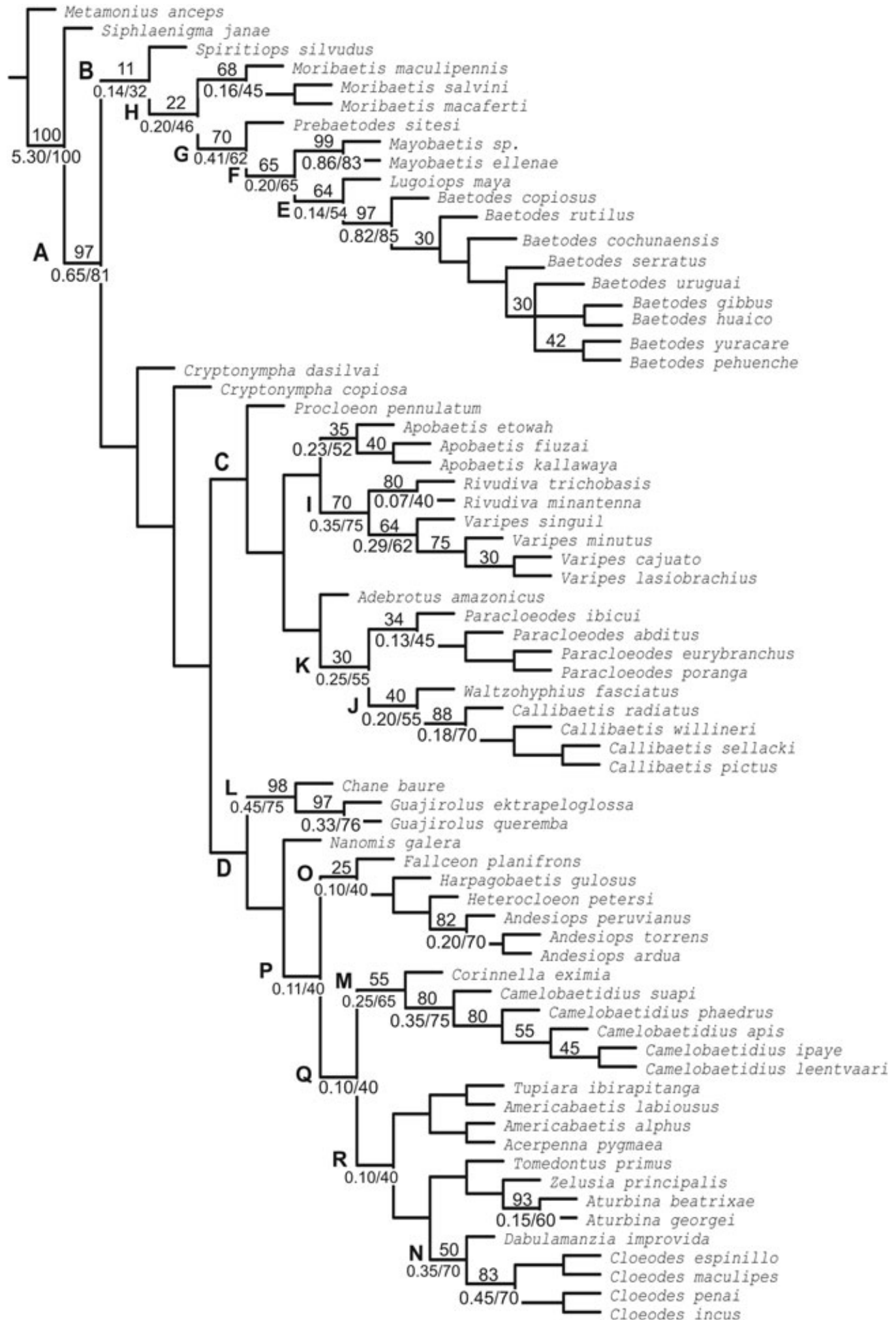

Fig. 73. Strict consensus of the three shortest trees obtained. The numbers above the nodes indicate frequency differences, unnumbered nodes have support less than 30 . The numbers below the nodes indicate absolute and relative Bremer supports. 


\section{References}

Baptista, D.F., Buss, D.F., Dias, L.G. et al. (2006) Functional feeding groups of Brazilian Ephemeroptera nymphs: ultrastructure of mouthparts. Annales de Limnologie, 42, 87-96.

Berner, L. \& Pescador, M.L. (1988) The Mayflies of Florida, revised edition. University Press of Florida, Tallahassee, Florida.

Bremer, K. (1988) The limits of amino-acid sequence data in angiosperm phylogenetic reconstructions. Evolution, 42, 795-803.

Bremer, K. (1994) Branch support and tree stability. Cladistics, 10, 295-304.

Brittain, J.E. \& Sartori, M. (2003) Ephemeroptera. Encyclopedia of Insects (ed. by V. H. Resh and R. T. Cardé), pp. 373-380. Academic Press, Amsterdam.

Domínguez, E. (1995) Cladistic analysis of the Ulmeritus-Ulmeritoides group (Ephemeroptera, Leptophlebiidae), with descriptions of five new species of Ulmeritoides. Journal of the New York Entomological Society, 103, 15-38.

Domínguez, E. (1999) Systematics, cladistics and biogeography of the American genus Farrodes (Ephemeroptera, Leptophlebiidae, Atalophlebiinae). Zoological Journal of the Linnean Society, 126, 155-189.

Domínguez, E., Ferreira, M.J. \& Nieto, C. (2001) Redescription and phylogenetic relationships of Leentvaaria Demoulin (Ephemeroptera: Leptophlebiidae). Trends in Research in Ephemeroptera and Plecoptera (ed. by E. Domínguez), pp. 313-320. Kluwer Academics/Plenum Press, New York, New York.

Domínguez, E., Molineri, C., Pescador, M.L., Hubbard, M.D. \& Nieto, C. (2006) Ephemeroptera of South America, Aquatic Biodiversity of Latin America, Vol. 2. Pensoft Press, Sofia and Moscow.

Farris, J.S., Albert, V.A., Källersjö, M., Lipscomb, D. \& Kluge, A.G. (1996) Parsimony jackknifing outperforms neighborjoining. Cladistics, 12, 99-124.

Flowers, R.W. \& Domínguez, E. (1991) Preliminary cladistics of the Hermanella complex (Ephemeroptera: Leptophlebiidae: Atalophlebiinae). Overview and Strategies of Ephemeroptera and Plecoptera (ed. by J. Alba-Tercedor and A. Sanchez-Ortega), pp. 49-62. Sandhill Crane Press, Gainesville, Florida.

Gattolliat, J.-L., Monaghan, M.T., Sartori, M. et al. (2008) A molecular analysis of the Afrotropical Baetidae. International Advances in the Ecology, Zoogeography and Systematics of Mayflies and Stoneflies (ed. by F. R. Hauer, J. A. Stanford and R. L. Newell), Vol. 128, pp. 219-232. University of California Publications in Entomology, University of California Publications in Entomology, California.

Gillies, M.T. (1991) A diphyletic origin for the two-tailed baetid larvae occurring in east African stony streams with a description of the new genus and species Tanzaniella spinosa gen. nov. sp. nov. Overview and Strategies of Ephemeroptera and Plecoptera (ed. by J. Alba-Tercedor and A. Sanchez-Ortega), pp. 175-187. Sandhill Crane Press, Gainesville, Florida.

Gillies, M.T. (2001) A new species of Aturbina (Ephemeroptera, Baetidae) Lugo-Ortiz \& McCafferty from Uruguay. Trends in Research in Ephemeroptera and Plecoptera (ed. by E. Domínguez), pp. 331-335. Kluwer Academic/Plenum, New York, New York.

Goloboff, P. (1993) Estimating character weights during tree search. Cladistics, 9, 83-91.

Goloboff, P., Farris, J.S. \& Nixon, K. (2003a) TNT: Tree Analysis. Program and documentation available from the authors [WWW document]. URL http://www.zmuc.dk/public/phylogeny [accessed on 7 January 2008].

Goloboff, P.A., Farris, J.S., Källersjö, M., Oxelman, B., Ramírez, M.J. \& Szumick, C. (2003b) Improvements to resampling measures of group support. Cladistics, 19, 324-332.
Kazlauskas, R.S. (1972) Neues über das system des Eintagsfliegen der Familie Baetidae (Ephemeroptera). Proceedings of the 13th International Congress of Entomology, Moscow, 1968 (ed. by R.E. Woodruff), Vol. 3, pp. 337-338. Academy of Sciences of the USSR, all Union Entomological Society, Moscow.

Kluge, N.Y.U. (1992) Cuban mayflies of the family Baetidae (Ephemeroptera). 2. Subgenera Caribaetis subgen. n. and Americabaetis subgen. $\mathrm{n}$. of the genus Baetis s.l. Zoologicheskii Zhurnal, 71, 13-20 (in Russian).

Kluge, N.Y.U. (1997) Classification and phylogeny of the Baetidae (Ephemeroptera) with description of the new species from Upper Cretaceous resins of Taimyr. Ephemeroptera and Plecoptera. Biology-Ecology and Systematics (ed. by P. Landolt and M. Sartori), pp. 527-535. Mauron + Tinguely y Lacht, Fribourg.

Kluge, N.Y.U. (2004) The Phylogenetic System of Ephemeroptera. Kluwer Academic Publishers, Dordrecht.

Landa, V. \& Soldán, T. (1985) Phylogeny and Higher Classification of the Order Ephemeroptera: A Discussion from the Comparative Anatomical Point of View. Studie Ceskoslovenská Akademie Ved, Prague.

Leach, W.E. (1815) Entomology. Brewster's Edinburgh. Encyclopaedia, 9, 57-172.

Lugo-Ortiz, C.R. \& McCafferty, W.P. (1996a) Phylogeny and classification of the Baetodes complex (Ephemeroptera: Baetidae), with description of a new genus. Journal of the North American Benthological Society, 15, 367-380.

Lugo-Ortiz, C.R. \& McCafferty, W.P. (1996b) Taxonomy of the Neotropical genus Americabaetis, new status (Insecta: Ephemeroptera: Baetidae). Studies on Neotropical Fauna and Environment, 31, 156-169.

Lugo-Ortiz, C.R. \& McCafferty, W.P. (1998) Five new genera of Baetidae (Insecta: Ephemeroptera) from South America. Annales de Limnologie-International Journal of Limnology, 34, 57-73.

Lugo-Ortiz, C.R., McCafferty, W.P. \& Waltz, R.D. (1994) Contribution to the taxonomy of the Panamerican genus Fallceon (Ephemeroptera: Baetidae). Journal of the New York Entomological Society, 102, 460-475.

McCafferty, W.P. \& Baumgardner, D.E. (2003) Lugoiops maya, a new genus and species of Ephemeroptera (Baetidae) from Central America. Proceedings of the Entomological Society of Washington, 105, 397-406.

McCafferty, W.P. \& Lugo-Ortiz, C.R. (1998) The adult of Moribaetis macaferti (Ephemeroptera: Baetidae). Entomological News, 109, $117-121$.

Molineri, C. (2004) Phylogeny of the Allenhyphes-Traverhyphes group (Ephemeroptera: Leptohyphidae), with new subgenera, species and combinations. Tijdschrift voor Entomologie, 147, 197-220.

Molineri, C. (2006) Phylogeny of the mayfly family Leptohyphidae (Insecta: Ephemeroptera) in South America. Systematic Entomology, 31, 711-728.

Monaghan, M.T., Gattolliat, J.L., Sartori, M. et al. (2005) Transoceanic and endemic origins of the small minnow mayflies (Ephemeroptera, Baetidae) of Madagascar. Proceedings of the Royal Society B, 272, 1829-1836.

Morrone, J.J. (2001) Biogeografía de América Latina y el Caribe,Manuales \& Tesis SEA, Vol. 3. Sociedad Entomológica Aragonesa, Zaragoza.

Nieto, C. (2004) The genus Baetodes (Ephemeroptera: Baetidae) in South America with the description of new species from Argentina, Bolivia and Peru. Studies on Neotropical Fauna and Environment, 39, 63-79.

Nieto, C. \& Richard, B. (2008) The genus Cloeodes (Ephemeroptera: Baetidae) in Argentina with new generic synonymy and new species. Zootaxa, 1727, 1-21. 
Nieto, C. \& Salles, F.F. (2006) Revision of the genus Paracloeodes (Ephemeroptera: Baetidae) in South America. Zootaxa, 1303, $1-33$.

Ogden, T.H. \& Whiting, M.F. (2005) Phylogeny of Ephemeroptera (mayflies) based on molecular evidence. Molecular Phylogenetics and Evolution, 37, 625-643.

Ogden, T.H., Gattolliat, J.L., Sartori, M., Staniczek, A.H., Soldan, T. \& Whiting, M.F. (2009) Towards a new paradigm in mayfly phylogeny (Ephemeroptera): combined analysis of morphological and molecular data. Systematic Entomology, 34, 616-634.

Perry, H.A. (2005) The life history and contribution to the ecology of Camelobaetidius variabilis Wiersema, 1998 (Ephemeroptera: Baetidae) in Honey Creek, Oklahoma. MS Thesis, University of North Texas, North Texas.
Pictet, F.J. (1843-1845) Histoire naturelle générale et particulière des Insectes Névroptères. Famille des Ephémérines. Baillière édit., Paris (Kessmann et Cherbuliez édit., aussi à Genève).

Salles, F.F. \& Francischetti, C.N. (2004) Cryptonympha dasilvai sp. nov. (Ephemeroptera: Baetidae) do Brasil. Neotropical Entomology, 33, 213-216.

Salles, F.F. \& Lugo-Ortiz, C.R. (2002) A distinctive new species of Apobaetis (Ephemeroptera: Baetidae) from Mato Grosso and Minas Gerais, Brazil. Zootaxa, 35, 1-6.

Waltz, R.D. \& McCafferty, W.P. (1985) Moribaetis: a new genus of Neotropical Baetidae (Ephemeroptera). Proceedings of the Entomological Society of Washington, 87, 239-251.

Accepted 21 December 2009

First published online 12 February 2010 